\title{
Komunikasi dan Analisis Media dalam Evakuasi Mahasiswa WNI dari Thailand Saat Pandemi COVID19
}

\author{
Dimas Prakoso Nugroho \\ ${ }^{1}$ Jurusan Komunikasi dan Penyiaran Islam/ FUAD/ IAIN Tulungagung. Tulungagung, \\ Indonesia
}

\begin{abstract}
ABSTRAK
Pendahuluan: Mahasiswa WNI peserta program KKN menjadi pihak yang rentan terjebak di luar negeri selama masa pandemi COVID19. Evakuasi mahasiswa menjadi solusi untuk menjamin keselamatan sekaligus bentuk perlindungan WNI. Perguruan tinggi sebagai pelaku hubungan luar negeri wajib melaksanakan perlindungan WNI salah satunya melalui evakuasi. Ketersediaan data, informasi dan akses komunikasi menjadi garda depan dalam proses evakuasi mahasiswa. Penelitan ini mengelaborasi bagaimana implementasi komunikasi dan analisis media dalam evakuasi mahasiswa WNI dari Thailand saat pandemi COVDI19. Tujuan makalah: penelitian ini ingin mengetahui implementasi komunikasi dan analisis media dalam evakuasi mahasiswa WNI saat pandemi COVID19. Penelitian ini dapat menjadi referensi bagi pengelola program luar negeri perguruan tinggi saat berhadapan dengan situasi krisis. Ketersediaan referensi ini penting internasionalisasi perguruan tinggi sedang gencar dilakukan namun best practice masih sangat minim. Metode: metode penelitian deskriptif kualititatif dinilai mampu menjadi pisau analisis untuk menjawab pertanyaan penelitian. Temuan: Komunikasi dengan berbagai pihak di dalam dan luar negeri dapat digunakan untuk membantu proses evakuasi. Banyaknya dari pemberitaan media, unggahan resmi dan utasan media sosial membuat penguasaan multimetode untuk melakukan analisa media penting dikuasai. Jumlah data dan informasi yang di analisa secara massif berpotensi menimbulkan stress di kalangan tim evakuasi Kesimpulan: Evakuasi mandiri dapat dilakukan oleh perguruan tinggi secara jarak jauh dengan berpegang pada jejaring komunikasi yang telah terjalin dengan baik dan kemampuan untuk melakukan analisa media mulai dari proses penelusuran informasi, verifikasi kebenaran informasi melalui fact Checking, hingga analisis framming media. Guna menyajikan informasi yang akurat, kredibel dan dapat digunakan dalam evakuasi, penguasaan multi metode analisa penting dimiliki oleh pusat data dan komunikasi.
\end{abstract}

Kata kunci: Evakuasi; COVID19; Komunikasi; Analisa Media; Framming; Fact Checking

\section{Communication and Media Analysist in Indonesia Citizen Evacuation from Thailand during COVID19 Pandemic}

\begin{abstract}
Introduction: Indonesian Students as participant in community service program overseas potentially stranded abroad during COVID19 pandemic. Evacuation is a solution to keep and protect their safety. Universities as foreign affairs operator must protect indonesian citizen abroad. data and information availability and communication acces are important in evacuation process. This research elaborates how the implementation of communication and media analysis in Indonesia citizen students evacuation from Thailand during COVID19 pandemic. Paper Purposes: the research purpose is to know the implementation of communication and media analysis in Indonesia citizen
\end{abstract}


students evacuation from Thailand during COVID19 pandemic. This research also can be used as a reference for Indonesia universities with operate International Program to face the crisis situation. Indonesian Universities has less best practice reference at the middle of their internationalization. Method: Qualitative descriptive research method believed to analyze and answer the research question. Findings: Communication with stakeholders inside and outside the country help the evacuation process. News, official information, social media post with disinformation and fakenews inside massively found during evacuation process. This situation rise the need of ability to implement the multi-method of media analysis. the massive data should be analyzed put the evacuation team in stressful situation. Conslusion: self evacuation can be done by using good communication network and media alaysis. the ability to use multi-method of media analysis from information tracking, fact checking, to framming analysis are important to provide high accuracy and credibility information for evacuation process .

Key Words: Evacuation; COVID19; Communication; Media Analysis; Framming; Fact Checking

\section{PENDAHULUAN}

Semua pihak yang yang terlibat dalam hubungan luar negeri bertanggungjawab untuk melaksanakan perlindungan WNI (UU RI Nomor 37, 1999). Perguruan tinggi dapat melakukan evakuasi mandiri pada civitas akademika yang terjebak di luar negeri saat pandemi COVID19. IAIN Tulungagung melakukan evakuasi pada mahasiswa di luar negeri saat awal pandemi COVID19. Data International Office IAIN Tulungagung menunjukkan 6 mahasiswa berpotensi terjebak pandemi COVID19 di Thailand (International Office IAIN Tulungagung, 2020). 6 orang mahasiswa ini adalah peserta program KKN luar negeri sebagai bentuk kolaborasi internasional perguruan tinggi. Program KKN luar negeri di Thailand berlokasi di kawasan minoritas muslim Pattani, Thailand Selatan. Kekhawatiran terjangkit COVID19 di Thailand dan tidak tersedianya transportasi menjadi pertimbangan evakuasi. Regulasi Kementerian Sekretariat Negara nomor B-18/Kemensetneg/Ses/LN.00/03/2020 perihal Kebijakan Pelaksanaan Perjalanan Dinas Luar Negeri (PDLN) dalam Upaya Pencegahan Penyebaran Coronavirus Disease (COVID19) yang melarang seluruh ASN untuk melaksanakan dinas luar negeri (Setneg, 2020) membuat evakuasi menjadi penuh tantangan.

Ada sejumlah faktor yang harus diperhatikan dalam evakuasi mandiri. Hubungan diplomatik Indonesia Thailand yang telah berjalan baik harus dijaga agar tidak menimbulkan kesan melanggar yuridiksi negara lain. Situasi sensitif ini berpotensi muncul karena lokasi KKN berada di kawasan minoritas yang rawan konflik bersenjata (Chambers, Jitpiromsri, Waitulkiat, 2019)(Wheller \& Chambers, 2019) (Chambers\&Waitoolkiat, 2019)(Jitpiromsri,2019). Lokasi KKN luar negeri ini juga dikenal sulit untuk mendapat akses informasi dan komunikasi. Sehingga proses komunikasi dengan para mahasiswa dan panitia setempat tidak berjalan lancar. Posisi Thailand Selatan yang berbatasan langsung dengan Malaysia membuat opsi evakuasi melalui Kuala Lumpur turut dipertimbangkan. Kemudahan akses transportasi darat dan jumlah penerbangan langsung ke Surabaya menjadi pertimbangan opsi tersebut. Di awal pandemi COVID19 masing masing negara ingin melakukan proteksi bagi warganya. Implikasi proteksi tersebut adalah cepatnya perubahan kebijakan luar negeri, regulasi penerbangan sipil, hingga kebijakan maskapai penerbangan. 
Proses evakuasi mandiri ini sepenuhnya mengandalkan kemampuan komunikasi dan analisa informasi. Tantangan evakuasi ini adalah varian informasi masih berupa puzzle berserakan yang harus di verifikasi dan dianalisis. Analisa Pemberitaan Media menjadi salah satu cara mendapatkan informasi. International Office IAIN Tulungagung sebagai unit kerja baru dengan jumlah sumber daya manusia terbatas ditugaskan menjadi pusat informasi dan komunikasi. International Office dituntut mampu merespon secara cepat, menyajikan informasi valid dan akurat, hingga membangun komunikasi di lingkungan internal dan eksternal.

Penelitian ini ingin mengelaborasi implementasi analisis media dan komunikasi dalam proses evakuasi mahasiswa WNI IAIN Tulungagung dari Thailand selama pandemi COVID19. Dinamika komunikasi ini menarik untuk diteliti guna memberikan referensi pentingnya kemampuan analisa media dan komunikasi di masa krisis oleh perguruan tinggi penyelenggara hubungan luar negeri. Referensi proses evakuasi mahasiswa WNI dalam konteks keilmuan komunikasi yang dilakukan perguruan tinggi di Indonesia masih sangat minim. Padahal referensi ini penting ditengah maraknya internasionalisasi perguruan tinggi. Situasi yang dihadapi oleh International Office IAIN Tulungagung ini pun juga berpotensi dihadapi oleh perguruan tinggi lain. Penelitian ini ingin memperkaya kajian tentang implementasi analisis media dan komunikasi internasional.

Penelitian ini menggunakan paradigm penelitian kualitatif yang menganalisis fenomena secara mendalam. Metode penelitian deskriptif kualitatif dinilai mampu digunakan sebagai pisau analisis. Penelitian ini dilakukan mulai Januari hingga Juni 2020. Teknik pengumpulan data dilakukan melalui observasi partisipan, wawancara mendalam dan studi literatur. Observasi partisipan dilakukan dengan menjadi insider dalam proses kerja International Office IAIN Tulungagung selama proses evakuasi pada bulan Februari hingga April 2020. Proses analisa data dilakukan secara deskriptif dengan menggabungkan hasil observasi partisipan, wawancara dan studi literature. Penarikan kesimpulan dilakukan dengan menggabungkan data data penelitian yang telah diperoleh.

\section{Evakuasi Mandiri Sebagai Bentuk Perlindungan WNI di Luar Negeri}

Undang Undang Nomor 37 tahun 1999 Tentang Hubungan Luar Negeri mengamanatkan pemerintah harus dapat mengambil langkah antisipatif atas berbagai situasi dan kondisi yang dialami oleh bangsa Indonesia, WNI dan kepentingannya di luar negeri (Pemerintah Indonesia, 1999). Prinsip prinsip perdamaian dan menghargai yuridiksi negara setempat saat melakukan aktivitas perlindungan harus tetap dikedepankan. Hal ini dipertegas kembali dalam Peraturan Menteri Luar Negeri nomor 5 tahun 2018 tentang Perlindungan Warga Negara Indonesia yang menyebutkan perlindungan dilakukan sesuai dengan aturan perundang undangan negara setempat dan kebiasaan internasional (Kemlu, 2018). Serangkaian regulasi perlindungan WNI di luar negeri tidak spesifik menyebutkan tentang pandemi. Namun perlindungan WNI di masa pandemi dirasa terwakili melalui pasal 21 Undang Undang Nomor 37 tahun 1999 tentang hubungan luar negeri. WNI yang terancam bahaya nyata wajib dilindungi oleh perwakilan Indonesia di luar negeri. KBRI dan KJRI wajib memberikan perlindungan, membantu dan menghimpun ke wilayah aman serta mengusahakan pemulangan. Pemenlu nomor 5 tahun 2018 tentang perlindungan WNI yang 
menyebutkan ada 6 keadaan darurat untuk melaksanakan perlindungan WNI yakni perang dan atau konflik, bencana alam, bencana non alam, bencana sosial, pemberlakuan kebijakan negara setempat yang berdampak langsung pada WNI, dan kondisi lain dimana WNI dinilai membutuhkan perlindungan segera. Menurut Permenlu nomor 4 tahun 2008 tentang pelayanan warga pada perwakilan RI di luar negeri, penentuan keadaan darurat ini dapat dilakukan dalam dua cara. Pertama, penentuan kedaruratan yang dilakukan sebagai hasil koordinasi dengan pemerintah negara setempat. Dua, hasil analisa dan pengamatan perwakilan Indonesia atas situasi dan kondisi di negara setempat (Kemlu. 2008).

Evakuasi didefinisikan sebagai situasi mendesak dan untuk segera memindahkan orang menjauh dari kawasan berbahaya menuju ke tempat yang lebih aman . Evakuasi WNI dari suatu negara dapat menjadi respon atas situasi darurat (Brooking Institution, UNHCR \& Georgetown University, 2014). Ada dua perspektif evakuasi WNI. Pertama, evakuasi dilakukan dan ditanggung oleh negara. Evakuasi WNI dari Hubei, Wuhan, Tiongkok termasuk dalam jenis ini. Dua, evakuasi yang dilakukan secara mandiri baik dengan atau tanpa melibatkan perwakilan RI di luar negeri. Evakuasi ini sering dikenal dengan istilah evakuasi mandiri atau repatriasi mandiri. Posisi negara dalam proses repatriasi mandiri adalah sebagai fasilitator. Evakuasi atas mahasiswa WNI IAIN Tulungagung dari Thailand Selatan termasuk dalam kategori ini. Sebab evakuasi ini dilakukan atas inisiatif IAIN Tulungagung sebelum adanya pengumuman keadaan darurat atau Emergency Decree oleh pemerintah Thailand.

\section{Gambaran Kasus Konfirmasi Positif COVID19 dan Urgensi Evakuasi}

Nama COVID19 pertama kali di umumkan oleh WHO pada 30 Januari 2020 (WHO, 2020). Jumlah kasus konfirmasi positif COVID19 juga terus mengalami peningkatan di berbagai negara. Hingga akhir Februari 2020 jumlah kasus konfirmasi positif COVID19 di Thailand mencapai 40 orang. Sementara itu jumlah kasus konfirmasi positif di Malaysia adalalh 20 orang. Jumlah konfirmasi positif di dua negara ini hampir seluruhnya berasal dari Tiongkok (WHO,2020). Kasus konfirmasi positif COVID19 belum ditemukan di Indonesia pada Februari 2020. Pada awal maret 2020 jumlah konfirmasi positif COVID19 di Malaysia terus mengalami peningkatan jumlah penderita. Sedangkan di Thailand kasus konfirmasi positif COVID19 relatif tidak bertambah WHO, 2020). Kasus konfirmasi positif pertama di Indonesia diumumkan pada 2 Maret 2020 dari peserta festival tari Internasional di Jakarta. Pada awal pandemi COVID19, jumlah konfirmasi positif di dominasi oleh mereka yang baru saja tiba dari luar negeri atau melakukan kontak dengan pelaku perjalanan luar negeri.

Meskipun jumlah konfirmasi kasus positif di Thailand relatif stabil, namun jumlah penderita di Malaysia terus mengalami peningkatan. Pemerintah Diraja Malaysia melakukan langkah penutupan sementara perbatasan Bukit Kayu Hitam (Malaysia) - Sadao (Thailand) pasca ditemukan kasus positif dari wisatawan pelintas batas. Pasca penutupan tersebut semua gate otomatis di immigration check point tersebut di non aktifkan yang mengharuskan pelintas batas melewati pemeriksaan imigrasi secara manual. Langkah serius penanganan COVID19 oleh pemerintah diraja Malaysia ditandai dengan pengumuman Perintah Kawalan Pergerakan oleh Perdana Menteri Muhyiddin Yassin pada 18 Maret 2020. Hal ini dilakukan pemerintah 
setempat setelah munculnya cluster baru COVID19 dari jamaah tabligh akbar di Masjid Sri Petaling, Putra Jaya. Jumlah penderita yang relative terkontrol di Thailand membuat mereka belum mengambil langkah seperti Malaysia. Bahkan Pemerintah Thailand justru disibukkan mencounter issue global tentang evakuasi keluarga kerajaan ke Jerman. Meskipun demikian pemerintah Thailand terus melakukan update penambahan harian kasus konfirmasi positif COVID19. Berangkat dari cepatnya perkembangan kasus COVID19 di Malaysia, situasi serupa juga berpotensi terjadi di Thailand. Pemerintah Thailand dapat mengambil langkah strategis seperrti penutupan penerbangan, pembatasan transit hingga pelarangan kedatangan dalam waktu singkat. Penambahan kasus secara signifikan yang berakibat pada munculnya Batasan kawalan Pergerakan di Malaysia membuat pemerintah Thailand mulai mengambil langkah serius. Hal ini mulai terasa hampir bertepatan dengan proses evakuasi mahasiswa WNI oleh IAIN Tulungagung. Situasi ini membuat urgensi evakuasi semakin tinggi. Memulangkan ke Indonesia adalah satu satunya langkah yang harus diambil untuk menjamin keselamatan mahasiswa di masa pandemi COVID19.

\section{Analisis Media dalam Evakuasi Mahasiswa WNI di Thailand}

Ketersediaan informasi menjadi faktor penentu keberhasilan evakuasi mandiri mahasiswa WNI yang dilakukan dari jarak jauh. Data dan informasi yang diperoleh tersebut tidak hanya disupply kepada pihak yang berhubungan dengan proses evakuasi. Di saat yang sama data tersebut juga 'dipanen' dari beragam sumber digital dan secara konsisten diperbaharui (Melissen, 2020) baik dari media maupun pihak pihak yang telah terjalin komunikasi sebelumnya. Informasi tentang jumlah dan profil yang akan dievakuasi, lokasi terakhir, situasi krisis di negara setempat, situasi kedaruratan, dan ketersediaan informasi penting untuk diketahui tim evakuasi (Mawbi\&Susan, 2016). Penggunaan data dan informasi dalam proses pelindungan warga negara juga telah banyak dilakukan. Pemerintah Kenya menggunakan data yang terkumpul dari twitter saat melakukan evakuasi warganya yang terjebak kekerasan di Sudan Selatan (Manor, 2019). Evakuasi banjir gempa bumi hingga evakuasi mahasiswa di Nepal juga mengandalkan informasi dan komunikasi.

Pemberitaan media menjadi salah satu sumber informasi. Namun pemberitaan ini tidak lepas dari kontruksi realitas dan realita yang dikontruksi sesuai preferensi media. Sehingga fakta yang diberitakan menjadi tersamarkan, tertutupi atau dibelokkan (Luhman,1996). Pesan dalam pemberitaan media juga tak lepas dari upaya komodifikasi informasi oleh media (Mosco.2006). Kontruksi informasi ini terlihat dari framing pemberitaan yang dibuat dengan penggabungan beberapa elemen kedalam sebuah narasi sehingga menimbulkan intepretasi tertentu (Entman.2007). Bagian yang dipilih untuk dinarasikan ini berpengaruh pada penilaian seseorang atas isi informasi (Pan and Kosicki, 1993).

Ada banyak framing berita tentang COVID19 yang dilakukan oleh media. Kemampuan analisis framming media dapat membantu menunjukan ketersediaan informasi yang relevan (Hertog and Mc Leod, 1995). Relevansi informasi dipengaruhi oleh apa yang disebut Niklas Luhman sebagai self reference dan other reference (Luhman, 1996). Self reference dalam proses evakuasi ini adalah faktor faktor yang menjadi pertimbangan internal IAIN Tulungagung. Sedangkan other reference berhubungan dengan pertimbangan eksternal. Self 
reference dan other reference ini bermatomorfosa menjadi kategorisasi yang dapat digunakan dalam proses analisa framming dalam rangka seleksi dan penjernihan informasi secara cepat untuk mendukung proses evakuasi.

Analisa framming Robert Entman dipilih oleh tim evakuasi International office untuk menganalisis pemberitaan media asing selama evakuasi. Entman membagi frammingnya kedalam 4 hal besar yakni Pertama, define problem yang menjelaskan persoalan apa yang diangkat dalam sebuah konten informasi. Dua, diagnose cause yang membahas penyebab dari diangkatnya persoalan tersebut. Tiga, make a moral judgement berupa penilaian atas konten informasi. Empat, suggest remedies berupa rekomendasi solusi yang diberikan atas konten. International Office IAIN Tulungagung dalam menganalisis pemberitaan media menggunakan metode ini agar dapat menyajikan informasi komprehensif.

Mc Luhan pada tahun 1962 membayangkan media sebagai global village yang memudahkan masyarakat mendapatkan informasi tanpa batas ruang dan zona waktu (McLuhan, 1962). Teknologi informasi merealisasikan apa yang direalisasikan oleh McLuhan. Teknologi informasi juga membuat munculnya sistem sosial yang sama dengan di dunia nyata dan saling terhubung (Van Dijk, 2006). Masing masing sistem ini memproduksi informasinya sendiri. Banyaknya varian informasi ini terkumpul menjadi satu di ranah daring. Banyaknya varian informasi ini membuat proses analisa media harus diperluas. Analisis media tidak hanya berbicara tentang konten media namun juga proses pencarian informasi yang relevan, verifikasi, hingga analisa konten.

Proses evakuasi selalu diwarnai oleh banyaknya fake news dan disinformasi (Melissen, 2020). Fact checking atau pengecekan fakta muncul sebagai metode baru untuk memastikan kebenaran informasi. Google News Initiatiave pada tahun 2016 meluncurkan serangkaian prosedur pengecekan fakta dan verifikasi sosial. Hal ini seiring dengan perkembangan algoritma yang mereka terapkan (Mantzarlis,2018). Pengusaan penggunaan fact checking diperlukan dalam proses evakuasi. Ada beberapa prosedur pengecekan fakta Google News Inititaive yang dapat digunakan dalam proses evakuasi ini. Pertama pengecekan situs untuk mengetahui kredibilitas website. Dua, melakukan pengecekan digital forensic foto. Tiga, melakukan verifikasi video. Empat, melakukan verifikasi lokasi. Lima melakukan analisa genealogy website. Enam, melakukan verifikasi waktu dan tanggal (AJI, 2019).

\section{METODOLOGI PENELITIAN}

Penelitian ini menggunakan paradigma penelitian kualitatif. Penelitian kualitatif ingin mendapatkan gambaran yang lebih mendalam tentang suatu kejadian atau fenomena. Penelitian kualitatif juga digunakan untuk mempertahankan bentuk dan isi poerilaku, menganalisis kualitasnya dibanding mengubah menjadi entitas kuantitatif (Mulyana, 2003). Metode penelitian deskriptif kualitatif dinilai mampu digunakan sebagai pisau analisis. Penelitian deskriptif membuat deskripsi atau gambaran secara sistematis factual dan akurat mengenai fenomena yang diselidiki (Wiksana, 2017). Penelitian deskriptif hanya memaparkan situasi atau peristiwa saja. Penelitian deskriptif tidak digunakan untuk mencari dan menjelaskan hubungan, tidak membuat hipotesis dan tidak membuat prediksi (Rakhmat, 
2002). Berdasarkan pendefinisian tersebut, penelitian ini menjelaskan fenomena penggunaan analisis media dalam evakuasi mahasiswa WNI dari Thailand.

Subjek dalam penelitian ini adalah International Office IAIN Tulungagung. Objek dalam penelitian ini adalah proses analisis media dan komunikasi luar negeri yang dilakukan International Office IAIN Tulungagung selama evakuasi mandiri mahasiswa WNI dari Thailand. Analisis media dalam penelitian ini meliputi proses pencarian informasi, verifikasi informasi, dan analisa konten informasi. Analisis media ini penting dikarenakan, pertama, proses evakuasi mandiri dilakukan secara remote dari Indonesia. Dua, batasan komunikasi membuat koordinasi antara tim evakuasi di Indonesia dengan mahasiswa dan panitia program KKN Luar Negeri tidak berjalan lancar.

Meskipun puncak evakuasi mandiri ini dilakukan pada bulan Maret 2020, namun penelitian ini dilakukan mulai bulan Januari hingga Juni 2020. Tahapan dalam penelitian ini sebagai berikut. Pertama, Penentuan topik penelitian yang dilakukan dengan memperhatikan fenomena pandemi COVID19 dan lalu lintas luar negeri civitas akademika IAIN Tulungagung. Dua, Penentuan fokus penelitian saat peneliti melihat indikasi secara non verbal kearah evakuasi sudah mulai terasa sejak februari. Tiga, pengumpulan data penelitian. Empat, seleksi data penelitian. Lima, Analisis data Penelitian. Enam, penulisan laporan penelitian.

Teknik pengumpulan data dilakukan melalui observasi partisipan, wawancara mendalam dan studi literatur. Observasi partisipan dilakukan dengan ikut serta dalam proses kerja yang dilakukan oleh International Office IAIN Tulungagung pada bulan Februari hingga April 2020. Observasi dilakukan dengan membuat catatan pengamatan harian atas kerja International Office. Wawancara dilakukan untuk memperkuat data observasi partisipan. Kriteria informan yang diwawancarai adalah orang orang yang terlibat proses evakuasi secara langsung yakni Wakil Rektor Bidang Kemahasiswaan dan Kejasama IAIN Tulungagung, Staf International Office, dan Kepala Pusat Pengabdian Kepada Masyarakat. Studi literatur dilakukan dengan mempelajari kebijakan hubungan luar negeri Indonesia, kebijakan tentang perlindungan WNI, kebijakan tentang evakuasi, metodologi dalam bidang komunikasi untuk verifikasi informasi dan analisa konten media. Analisis data observasi partisipan dan wawancara mendalam dilakukan dengan cara deskriptif.

\section{HASIL DAN PEMBAHASAN}

\section{International Office IAIN Tulungagung di Awal Pandemi COVID19}

Di awal pandemi COVID19 di Indonesia, International Office IAIN Tulungagung disibukkan dengan agenda penjadwalan ulang semua agenda luar negeri tahun 2020 dengan para stakeholder di Thailand, Malaysia, Filipina, Tiongkok, Jepang, Amerika Serikat, Belanda, Mesir dan Iran (International Office, 2020). Pasca rapat bersama 15 perguruan tinggi Amerika Serikat yang difasilitasi oleh US Consulate General Office Surabaya pada 11 Februari 2020 monitoring perkembangan COVID19 makin gencar dilakukan. Hasil wawancara dengan Nurul Ihsan staff International Office IAIN Tulungagung menunjukkan 
monitoring atas isu virus corona telah dilakukan sejak Desember 2019 dengan memantau media briefing WHO, pemberitaan covid di luar negeri. Tidak hanya itu, sejak Februari 2020 International Office juga memberikan layanan khusus pada para civitas akademika yang baru kembali dari luar negeri. Layanan ini berupa pencegahan persebaran COVID19 bekerjasama dengan Dinas Kesehatan setempat dan pendampingan psikologis civitas akademika yang sedang menjalani karantina mandiri sepulang dari luar negeri.

Komunikasi dengan berbagai entitas gencar dilakukan untuk mendapat update informasi di berbagai negara. Komunikasi dengan berbagai pihak ini juga menjadi kunci keberhasilan evakuasi mahasiswa Nepal dari Wuhan (Rajbhandari at all, 2020). Monitoring perkembangan COVID19 juga makin intens selama proses evakuasi WNI dari Wuhan. Menurut Nurul Ihsan International Office merasa perlu untuk melakukan monitoring proses ini dan komunikasi intensif dengan para pihak yang terlibat mengingat IAIN Tulungagung juga memiliki banyak program luar negeri dan potensi untuk melakukan evakuasi mandiri dapat menimpa siapa saja. Komunikasi intensif dengan Humas Universitas Negeri Surabaya pun segera dibangun sesaat setelah evakuasi dari Wuhan. Menurut staf International Office Mufti Rasyid komunikasi dengan UNESA ini untuk mendapatkan gambaran best practice evakuasi mahasiswa dari luar negeri. Pengalaman UNESA dapat memberikan jika IAIN Tulungagung harus melakukan evakuasi.

International Office juga gencar membangun komunikasi intensif dengan Kantor Imigrasi Kelas 2 Blitar dan Dinas Kesehatan Tulungagung terkait lalu lintas luar negeri. Komunikasi dengan perwakilan Indonesia di luar negeri yakni KBRI Manila, KJRI Davao, KJRI Songkhla dan KBRI Bangkok juga turut diperkuat. Filipina dan Thailand adalah negara asal mahasiswa dan calon mahasiswa IAIN Tulungagung. Komunikasi dengan KBRI Kuala Lumpur juga dibuka saat jumlah konfirmasi positif COVID19 di Asia Tenggara bertambah signifikan. Posisi Malaysia sebagai penghubung penerbangan global sekaligus jalur utama dalam lalu lintas mahasiswa asal Thailand maupun mahasiswa peserta program KKN di Thailand Selatan menjadi alasan dibukanya komunikasi ini. Efek positif dari komunikasi ini adalah supply informasi terkait regulasi dan immigration check point di Malaysia.

Wawancara dengan Wakil Rektor Bidang Kemahasiswaan dan Kerjasama IAIN Tulungagung Dr. H. Abad Badruzzaman, Lc., M.Ag menunjukkan International Office telah memiliki protokol untuk menangani civitas akademika yang baru kembali dari luar negeri. Hal ini telah diimplementasikan saat menghadapi mahasiswa yang baru kembali dari Malaysia awal Maret 2020. International Office memberikan layanan khusus seperti meminta civitas akademika yang baru kembali dari luar negeri melakukan karantina mandiri selama 14 hari, meminta civitas akademika secara pro aktif melapor pada Dinas Kesehatan setempat, membantu melaporkan civitas akademika yang baru kembali dari luar negeri untuk mendapatkan pengawasan medis, Hingga melakukan pendampingan untuk menjaga kondisi psikologis civitas akademika yang baru kembali dari luar negeri. Kesiapan dan jejaring inilah yang membuat International Office dipilih sebagai pusat informasi dan komunikasi luar negeri dalam evakuasi mahasiswa WNI pada 4 Maret 2020. 
Menurut Nurul Ihsan International Office langsung memutuskan untuk memberikan opsi evakuasi begitu mendengar ada mahasiswa yang sedang KKN di Thailand. Rekomendasi ini di dasarkan pada tren perjalanan yang mulai banyak berkurang dan sebaran negara terjangkit COVID19 sebagai hasil pemantauan sejak virus ini mulai muncul di Wuhan. Wawancara dengan Kepala Pusat Pengabdian Pada Masyarakat IAIN Tulungagung Dr. Muntahibun Nafis menunjukkan International Office juga langsung berkomunikasi dengan berbagai pihak di luar negeri yang hasilnya berupa data awal rencana evakuasi yang dirilis pada 6 Maret 2020 (International Office IAIN Tulungagung, 2020). Nafis juga menambahkan pada tanggal 11 maret 2020 International Office kembali merilis update situasi dan rekomendasi jalur evakuasi. Ada tiga opsi rute evakuasi yang dipersiapkan International Office IAIN Tulungagung. Pertama, Evakuasi mahasiswa menggunakan melalui perbatasan Sadao, Thailand - Bukit Kayu Hitam Malaysia menuju ke Kuala Lumpur guna diterbangkan langsung ke Surabaya. Dua, menerbangkan mahasiswa melalui Bandara Internasional Hatyai Thailand ke Surabaya dengan transit di Kuala Lumpur. Tiga, Evakuasi mahasiswa melalui jalan dart ke Bangkok dan diterbangkan menggunakan penerbangan Bangkok - Jakarta atau Surabaya baik dengan transit di Kuala Lumpur maupun penerbangan langsung (International Office IAIN Tulungagung, 2020). Pada tanggal 15 Maret 2020 International Office merilis laporan mereka terkait lalu lintas luar negeri civitas akademika IAIN Tulungagung yang dijelaskan langsung oleh Wakil rektor bidang kemahasiswaan dan kerjasama dalam rapat penentuan kebijakan pencegahan COVID19.

Dari tiga opsi yang diberikan International, opsi ketigalah yang kemudian direalisasikan saat menit menit terakhir. Awalnya evakuasi masih akan tetap dilakukan melalui Malaysia. Namun kemunculan cluster baru dari jamaah tabligh akbar di masjid Sri Petaling, Putra Jaya membuat angka konfirmasi positif COVID19 di Malaysia melonjak dastis yang direspon oleh Perdana Menteri Malaysia Muhyiddin Yasin dengan menutup semua perbatasan darat, laut, dan udara (kebijakan malay). Kuala Lumpur International Airport menjadi satu satunya pintu kelaur masuk Malaysia. Pemerintah Malaysia masih mengizinkan warga negara asing connecting flight di KLIA. Sesaat setelah pengumumanini tim evakuasi melakukan reroute penerbangan Kuala Lumpur - Surabaya menjadi Bangkok - Kuala Lumpur - Surabaya. 2 x 24 jam sebelum keberangkatan pihak maskapai membatalkan semua penerbangan ke seluruh destinasi di dalam dan luar negeri. Informasi tersebut juga menyebutkan penutupan semua bandara di Thailand dan menyisakan bandara Svarnabhumi sebagai akses utama keluar masuk Thailand. Di saat yang sama para mahasiswa sedang menuju ke bandara Dong Muang tempat mereka dijadwalkan terbang. Pembagian tugas anatara Pusat Pengabdian kepada Masyarakat dengan International Office pun dilakukan. Pusat Pengabdian kepada Masyarakat bertugas menjalin komunikasi intensif dan menenangkan mahasiswa. Sementara International Office mencari bantuan dari berbagai pihak salah satunya KBRI Bangkok.

Selama proses evakuasi, Tim International Office melakukan monitoring selama 24 jam non stop baik dari kantor maupun dari rumah. Koordinasi dengan tim evakuasi bahkan pernah dilakukan pada pukul 2 dini hari. Menurut Mufti Rasyid hal ini dilakukan international office untuk mendapatkan first hand information mengingat di awal masa pandemi penuh dengan ketidakpastian. International office pun membagi tim pada malam hari untuk monitoring 
informasi. Saat mengetahui adanya pembatalan penerbangan, International Office langsung menghubungi berbagai pihak di luar negeri untuk membantu proses evakuasi. Saat situasi genting ini justru muncul fakta baru dimana bukan hanya 6 mahasiswa IAIN Tulungagung yang berpotensi 'stranded' namun ada 48 mahasiswa dari 10 perguran tinggi lain yang juga terancam terlantar. 10 perguruan tinggi ini umumnya belum memiliki tim task force. Menurut Muntahibun Nafis situasi ini membuat fokus evakuasi diperlebar dengan ikut menyertakan 48 mahasiswa lain dalam proses ini. Saat itu juga dilakukan pembagian tugas dimana International Office fokus pada proses analisa data, komunikasi luar negeri dan prioritas membawa mahasiswa IAIN Tulungagung ke safe place yang telah disediakan dengan bantuan KBRI Bangkok. Sedangkan Pusat Pengabdian Kepada masyarakat fokus pada komunikasi dengan 10 perguruan tinggi lain dan meminta mereka untuk segera mengambil langkah.

Proses komunikasi antara International Office dan KBRI Bangkok dilakukan sejak para mahasiswa sedangdalam perjalanan menuju bandara Dong Muang. Saat pertama mendapat informasi ini pihak KBRI Bangkok tidak terlalu banyak merespon. Bahkan komunikasi sempat tersendat selama beberapa jam. Saat berusaha di konfirmasi oleh tim evakuasi, KBRI Bangkok hanya meminta untuk menunggu. Baru saat mahasiswa telah berada di bandara Dong Muang selama beberapa jam, KBRI Bangkok kembali merespon. Menurut Nurul Ihsan, jeda waktu dimana proses komunikasi tersendat tersebut karena KBRI Bangkok sedang mempersiapkan segala sesuatu di Thailand. Ihsan juga menambahkan saat kembali terhubung dengan KBRI Bangkok, mereka sudah memiliki opsi safe place berupa beberapa pilihan hotel di sekitar bandara Svarnabhumi. KBRI Bangkok juga memastikan terkait penutupan bandara, pembatalan maskapai hingga ketersediaan maskapai dalam waktu dekat. KBRI Bangkok menginformasikan hanya ada satu maskapai yang tersedia untuk terbang ke Indonesia dalam waktu 2 x 24 jam mendatang yakni Garuda Indonesia Bangkok - Jakarta. KBRI Bangkok juga membantu proses evakuasi dari bandara Dong Muang ke safe place. KBRI juga meminta maskapai untuk memastikan ketersediaan penerbangan dari Jakarta ke daerah, memudahkan proses Connecting flight di Jakarta dan memastikan semua bagasi mahasiswa terangkut hingga ke Surabaya. Ihsan juga menambahkan informasi ini langsung disampaikan kepada Pusat Pengabdian Kepada Masyarakat. Intenrational Office merekomendasikan untuk mengikuti arahan KBRI atas dasar pertimbangan safety para mahasiswa IAIN Tulungagung dan meminta agar opsi ini juga dikomunikasikan dengan 10 perguruan tinggi lain. Setelah semua proses evakuasi berjalan, tim evakuasi berkomunikasi dengan dinas sebagai bentuk antisipasi persebaran covid. Tim evakuasi juga terus melakukan pendampingan kepada para mahasiswa dan tim penjemput selama proses karantina mandiri selama 14 hari.

\section{Tracking dan Verifikasi Informasi oleh International Office dalam Proses Evakuasi}

Proses evakuasi mahasiswa WNI yang dilakukan oleh International Office bersama Pusat pengabdian Kepada Masyarakat seharusnya akan mudah dilakukan dengan pengiriman tim ke luar negeri. Namun komitmen proteksi pemerintah dengan melarang perjalanan luar negeri membuat proses ini harus dilakukan secara remote. Supply informasi menjadi kunci keberhasilan evakuasi ini. Informasi yang umumnya di dapat dari media dan unggahan harus diberikan sejumlah perlakuan hingga benar benar terjamin validitas dan akurainya. 
Berdasarkan pengamatan pada proses kerja International Office IAIN Tulungagung ada tiga perlakuan atas informasi yang diperoleh. Pertama, pemetaan jenis informasi yang dibutuhkan. Kondisi terkini persebaran COVID 19 secara global, di Indonesia, Thailand dan Malaysia dibutuhkan untuk memberikan gambaran tingkat bahaya yang mungkin dihadapi para mahasiswa. Kebijakan penerbangan di Thailand, Malaysia dan Indonesia juga harus dimiliki mengingat dinamika perubahan yang terjadi dengan sangat cepat. Informasi terkait protokol kesehatan bagi pelintas batas baik di Thailand, Malaysia dan Indonesia juga penting untuk dimiliki sebagai bahan edukasi bagi para mahasiswa dan tim penjemput. Kebijakan luar negeri Indonesia, Thailand dan Malaysia penting diketahui untuk menjaga hubungan diplomatik antar negara dan memudahkan proses evakuasi. Pemetaan situasi keamanan, politik, dan sosial di Thailand juga penting diketahui tim evakuasi untuk membaca apakah aka nada potensi bahaya bagi proses evakuasi. Sebab posisi mahasiswa saat itu berada di kawasan minoritas muslim Thailand Selatan yang rawan konflik. Mengetahui potensi pergolakan sedini mungkin akan memudahkan dalam proses evakuasi. Selain itu Kerajaan Thailand sedang mendapatkan sorotan global akibat langkah yang diambil Raja Rama V memboyong seluruh anggota kerajaan ke Jerman untuk menghindari pandemi di negara tersebut.

Dua, Pemetaan sumber informasi sebagai bagian dari verifikasi. Ada empat jenis sumber informasi yang digunakan dalam proses evakuasi ini. Pertama, Website dan Youtube channel media luar negeri. Penggunaan web dan channel media internasional ini penting untuk mendapatkan berita terbaru seperti yang sudah dijelaskan pada paragraph sebelumnya. International Office memilih menggunakan pemberitaan media luar negeri lantaran tidak banyak situs berita dari Thailand yang ditulis menggunakan huruf alphabet atau dapat di translate ke bahasa Inggris. Sementara itu kecepatan dan akurasi sangat dituntut. Dua, website dan akun instagram KBRI Bangkok dan KJRI Songkhla untuk memantau langkah langkah perlindungan kepada WNI. Tiga, Website dan Youtube Channel Mofa Indonesia milik Kementerian Luar Negeri Republik Indonesia untuk memantau kebijakan luar negeri pemerintah Indonesia. Empat, website milik Civil Aviation Authority of Thailand - CAAT untuk memantau kebijakan penerbangan yang ada di Thailand.

Menurut Mufti Rasyid, ada tiga syarat media asing yang mendapat prioritas monitoring International Office selama proses evakuasi. Pertama, siaran media di-streaming - kan melalui situs berbagi video YouTube. Dua, Kredibilitas media luar negeri. Pemberitaan media kredibel akan mempermudah proses analisa. Tiga, kedekatan atau proximity antara media dengan Thailand. Media yang berasal dari Asia dinilai memiliki porsi pemberitaan tentang Thailand lebih banyak. Mufti juga menambahkan International Office juga melakukan kategorisasi media berdasarkan intensitas pemantauan. Pertama adalah media luar negeri yang dimonitor secara intensif yakni Channel News Asia (CNA) dari Singapura, Kantor Berita Bernama (Bernama Tv) dari Malaysia, China Global Television Network (CGTN) dari Tiongkok, Al Jazeera dari Qatar, dan NHK dari Jepang. Banyaknya media yang dimonitor secara intensif ini untuk mengantisipasi perbedaan jam siar berita. Dua, media yang tidak secara intens di monitor namun pemberitaannya dipercaya dapat memberikan sudut pandang lain yakni ABC dari Australia, Bloomberg Global dari Amerika Serikat dan 
Euronews dari Perancis. Proses monitoring sendiri dilakukan dengan memutar siaran tersebut secara bersamaan pada semua komputer di International Office menggunakan fitur new windows tab. Salah satu staff di international Office bertugas untuk memonitor semua siaran media luar negeri tersebut dan melaporkannya setiap jam.

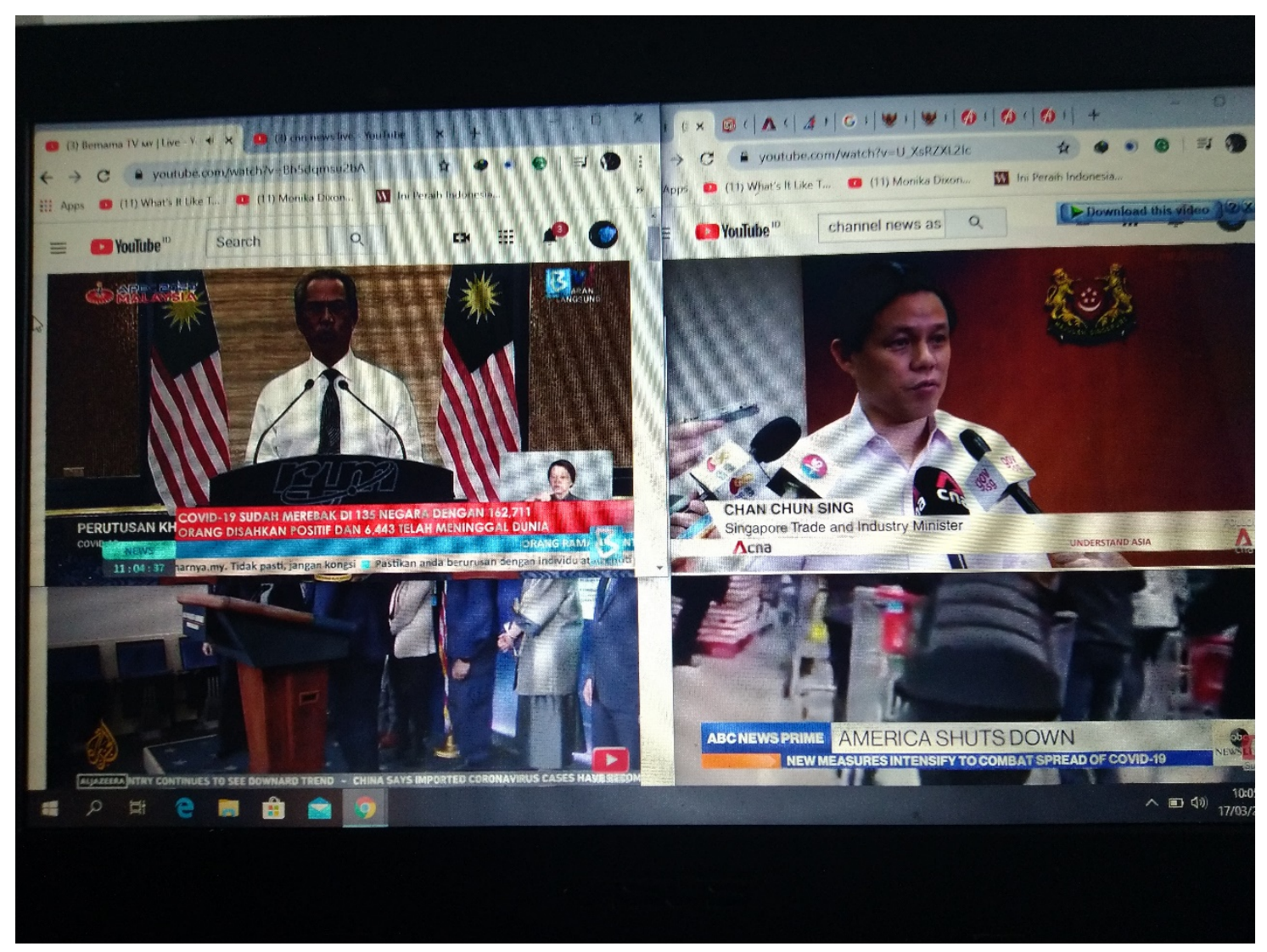

Tiga, analisis konten informasi untuk memastika isi pemberitaan. Sebelum menganalisa konten informasi dilakukan kategorisasi terlebih dahulu. Kategori pertama pemberitaan media dalam dan luar negeri. Kategori dua adalah konten informasi resmi dan diunggah pada website maupun akun media sosial lembaga yang telah ditentukan pada bagian sebelumnya. Kategori tiga konten informasi dari unggahan media sosial. Kategori empat adalah konten informasi dari hasil komunikasi dengan stakeholder. Verifikasi dilakukan setelah kategorisasi. Verifikasi kategori pertama dan kedua dilakukan dengan pengecekan langsung website lembaga. Hasil verifikasi dianggap valid jika konten informasi ditemukan dalam website. Informasi yang dinyatakan valid dilakukan analisis mengunakan analisa framing Robert Entman. Menurut Mufti analisis framming Robert Entman dipilih untuk melakukan identifikasi konten secara mendalam dengan waktu yang cepat. Empat tahapan analisa Entman digunakan sebagai berikut. Pertama, define problem, untuk menelusuri isu apa yang sedang dibahas dalam pemberitaan. Dua, Diagnose Cause untuk mencari alasan dimuatnya berita tersebut. Tiga, Make a moral judgement untuk menilai apakah informasi tersebutr dapat digunakan dalam proses evakuasi atau tidak. Empat, suggest remedies untuk memutuskan informasi akan digunakan atau tidak berikut dampak jika digunakan atau tidak digunakan. 
Pemrosesan informasi yang tidak ditemukan diperlakukan seperti pada kategori tiga dan empat. Verifikasi kategori tiga dan empat dilakukan dimulai dengan pengecekan informasi ke ke situs lembaga terkait dan pemberitaan media mainstream. Jika informasi tidak ditemukan atau hasil pencarian terlalu banyak, dilakukan pencarian mendalam menggunakan fitur google advance searching. Hasil pencarian ini dianalisa dengan memperhatikan prinsip prinsip fact checking yakni pertama identifikasi kredibilitas website. Dua, verifikasi genealogy website. Untuk konten berupa foto dan video akan ditelusuri terlebih dahulu kebenarannya menggunakan sejumlah piranti google reverse image, tineye, yandex, rev eye. Foto yang dirasa janggal juga dilakukan analisa data forensic dengan melakukan pengecekan exif. Verifikasi lokasi dan waktu juga dilakukan saat masih ditemukan kejanggalan.

\section{Efek Psikologis Evakuasi Pada Tim International Office}

Evakuasi mahasiswa WNI dari Thailand berjalan dengan sangat ketat diselimuti tekanan dan kekhawatiran. Hasil observasi menunjukkan ada sejumlah tekanan yang diterima tim International Office. Tekanan prioritas keselamatan mahasiswa. Persebaran COVID19 secara massif di luar negeri meningkatkan tekanan untuk memprioritaskan keselamatan mereka. Dua, Kekhawatiran Mahasiswa Terlantar akibat perubahan kebijakan luar negeri dan aturan penerbangan sipil. Tiga, Kekhawatiran munculnya stigma sebagai pembawa virus pada mahasiswa dan tim penjemput. Pengalaman International Office menangani civitas akademika yang kembali dari luar negeri sebelum proses evakuasi menunjukkan, publik cenderung menstigma mereka dari luar negeri sebagai pembawa virus. Empat, Kekhawatiran munculnya cluster baru COVID19 dari IAIN Tulungagung dari mereka civitas akademika yang beru kembali ke tanah air. Lima, Tekanan sosial rekan sejawat. Selama awal pandemi COVID19 civitas akademika IAIN Tulungagung diliputi kekhawatiran yang didominasi suasana saling curiga. Informasi COVID19 dan riwayat perjalanan dapat berujung pada ketakutan massal dan stigma. Situasi ini jelas memberikan tekanan pada tim evakuasi. Enam, Tekanan melakukan evakuasi secara damai. Suasana yang digambarkan pada poin 5 membuat pimpinan meminta evakuasi dilakukan secara damai dengan sesedikit mungkin pihak yang mengetahui untuk menjaga stabilitas dan mereduksi ketakutan sejawat.

Menurut Nurul Ihsan tekanan tekanan tersebut juga dipertimbangkan International Office dalam analisa informasi dan komunikasi. Data dan informasi tidak hanya untuk membantu proses evakuasi tetapi juga meng-counter isu isu liar di kalangan internal. Banyaknya pekerjaan dan situasi penuh tekanan ini membuat tim International Office hanya beristirahat antara 2 hingga 3 jam per hari selama evakuasi. Menurut Mufti Rasyid hal ini membuat tim International Office mengalami serangan psikosomatis dan perubahan emosional. Setiap memulai proses analisis anggota tim merasa menderita gejala mirip COVID19. Hasil observasi menunjukkan sebelum dan di awal proses evakuasi emosional tim masih stabil. Perubahan emosional terjadi terutama saat terjadi masalah penerbangan. Tekanan untuk bekerja dalam diam juga dinilai berkontribusi dalam meningkatkan emosional dan stress tersebut. Menurut Nurul Ihsan langkah yang diambil untuk menjaga kondisi psikis saat itu adalah dengan saling mengingatkan dan memberi waktu untuk beristirahat saat mulai terlihat emosi yang tidak stabil. Hasil observasi juga menunjukkan mereka yang telah beristirahat selama satu jam relative lebih stabis dan fresh saat harus melakukan analisa kembali. 


\section{Kerjasama Luar Negeri Sebuah Pisau Bermata Dua}

Keputusan Dirjen Pendis Nomor 129 Tahun 2018 tentang Petunjuk Teknis Pelaksanaan Kerjasama Luar Negeri Pada Perguruan Tinggi Keagamaan Islam Kementerian Agama menjadi penanda dimulainya kolaborasi global kampus kampus kemenag (Kemenag, 2018). Tujuan dari kerjasama ini adalah untung meningkatkan kinerja pendidikan tinggi (Kemdikbud, 2007). Kerjasama luar negeri juga berpengaruh pada reputasi perguruan tinggi secara global. Bahkan internasionalisasi ini secara tegas juga menjadi penilaian dari sejumlah badan pemeringkatan perguruan tinggi dunia. Times Higher Education menyebut penilaian ini dengan International outlook yang meliputi proporsi mahasiswa internasional, proporsi dosen internasional dan hasil publikasi ilmiah(THE, 2018). QS World University rank juga menambahkan pentingnya dibangun iklim multinasional dan fasilitasi program pertukaran secara global (QS World, 2020). Kerjasama luar negeri menjanjikan reputasi dan pengakuan global yang berbanding lurus dengan kualitas perguruan tinggi di kancah internasional. Sejumlah regulasi yang ada mempersiapkan perguruan tinggi untuk mencapai World Class University.

Pandemi Covid19 memberikan pelajaran berharga dalam proses pengelolaan kolaborasi internasional di lingkungan perguruan tinggi di Indonesia. Kolaborasi global harus dipahami secara utuh baik dari sisi benefit dan segala resikonya. Pengalaman International Office IAIN Tulungagung menunjukkan kolaborasi global tidak dibangun dalam satu malam. Ada banyak faktor yang harus dipersiapkan dan di maintenance dalam kolaborasi global. International Office IAIN Tulungagung adalah unit kerja yang beru berusia 1 tahun saat pandemi terjadi. Namun jalur komunikasi dan jejaring yang telah dibangun sebelumnya sangat bermanfaat dalam situasi darurat. Pandemi ini juga menunjukkan penguasaan komunikasi dan analisis media adalah skill mutlak yang harus dimiliki satf International Office. Aksesibilitas informasi dan kemudahan komunikasi menjadi garda depan dalam proses ini. Larangan perjalanan dinas luar negeri di masa pandemi memaksa proses evakuasi dilakukan secara remote dengan bertumpu pada supply informasi yang cepat dan akurat. Di sisi lain hal ini menimbulkan tantangan tersendiri. Perkembangan teknologi membuat seseorang atau lembaga menjadi prosumer informasi pada saat yang sama. Sehingga muncul sangat banyak varian informasi yang ditemukan di ranah daring.

Pengalaman melakukan evakuasi ini juga menunjukkan pentingnya faktor kemanusiaan dan sosial melalui komunikasi. Empati pada mahasiswa yang dievakuasi harus berada di garda depan. Komunikasi dan relasi yang terjalin baik terbukti memudahkan proses evakuasi. Sejak awal pandemi, International Office telah gencar melakukan analisa dan membangun komunikasi dengan stakeholder. Jalur yang telah terbangun dengan mudah digunakan dalam keadaan darurat.

\section{Urgensi Penguasaan Analisis Media dalam Evakuasi Mahasiswa WNI saat Pandemi Covid19}

Evakuasi mahasiswa WNI dari Thailand ini menunjukkan data hasil penelusuran informasi tidak dapat serta merta dijadikan patokan pengambilan keputusan. Disruptif informasi dan 
bias informasi banyak dihadapi dalam situasi krisis (Melissen, 2019). Informasi tersebut harus dianalisis secara komprehensif. Proses analisa informasi juga tidak cukup dengan satu jenis metode. Penguasaan multimetode diperlukan agar terserap sari informasi yang dapat langsung dieksekusi secara cepat dan akurat. Penggunaan analisis framing Robert Entman dalam proses evakuasi ini dapat digunakan untuk menilai secara cepat informasi yang diambil dari media. Analsia ini dilakukan untuk menjernihkan informasi dari kepentingan media yang tidak relevan dengan proses evakuasi. Namun analisa ini membutuhkan kemampuan memahami dan membaca cara kerja media. Kategorisasi sumber informasi media menjadi penting untuk mendukung proses analisa framing.

Pada awal pandemi COVID19 tidak banyak data strategis yang ditemukan. Mayoritas data yang dibutuhkan terbungkus dengan informasi dan fenomena lain. Indikasi hoax pun bertebaran di awal pandemi. Teknik fact checking digunakan untuk memastikan informasi yang didapatkan penting untuk digunakan dalam evakuasi mahasiswa WNI secara remote. Teknik fact checking untuk membantu proses evakuasi adalah sama dengan yang digunakan oleh newsroom. Penggunaan metode fact checking untuk memeriksa fakta sebenarnya bukan hal baru di kalangan media. Meskipun demikian tidak semua jurnalis memiliki skill ini. Sedikitnya ada 4 jenis pengecekan fakta yang diimplementasikan selama evakuasi ini. Masing masing pengecekan memiliki banyak tahapan dan tools yang digunakan. Hasil pengecekan tersebut juga masih harus dianalisa. Meskipun tidak mudah dilakukan, pengecekan fakta ini dapat langsung memberikan informasi yang terverifikasi kebenarannya. Analisis media ini dapat menjadi opsi lain untuk menjalankan proses evakuasi terhadap mahasiswa WNI dari luar negeri. Sehingga meskipun proses evakuasi konvensional dengan memberangkatkan tim tidak dilakukan, namun proses ini masih dapat dikerjakan secara remote. Kemampuan memadukan analisa media dan pengecekan kebenaran ini penting untuk dimiliki sebagai antisipasi peristiwa seupa di masa yang akan datang.

\section{Pentingnya Stress Management dan Stress Healing dalam proses Evakuasi Mandiri}

Ketika melakukan proses pencarian, verifikasi dan analisa informasi, tim international office bekerja layaknya spons yang menyerap air. Mereka menyerap semua jenis informasi untuk di verifikasi dan di analisis. Hasil observasi juga menujukkan proses analisa tersebut tidak berdiri sendiri. Saat memverifikasi dan analisa informasi tim juga masih memonitor siaran media asing. Telinga mereka masih mendengarkan konten informasi dari media. Mata mereka juga sesekali melihat VTW dan running text di semua layar. Terkadang jika semua media menyajikan informasi yang bagus secara bersamaan maka audio di seluruh layar akan diaktifkan. Proses ini sebenarnya sudah sangat berat. Beratnya proses analisis ini juga ditambah dengan banyaknya tekanan sosial. Banyaknya data dan informasi yang diserap membuat tim International Office merasa memiliki gejala COVID19 setiap kali melakukan analisa informasi. Sedangkan emosional yang labil disebabkan sebagai respon pada tekanan sosial yang mereka terima dan komitmen atas keberhasilan evakuasi.

Manajemen stress diperlukan untuk mengelola tekanan yang dapat memberikan efek psikologis. Memberikan ruang untuk beristirahat dan tidur sejenak menjadi bentuk stress management tersebut. Kepedulian seperti ini penting mengingat proses evakuasi yang serba 
tidak terduga membutuhkan endurance dari semua pihak. Kemampuan melakukan stress healing juga penting dimiliki. Pengalaman evakuasi ini mengajarkan pentingnya penguasaan kemampuan dasar stress healing. Cara sederhana yang dilakukan tim International Office adalah menarik nafas dalam beurlang kali saat mulai merasakan adanya perubahan emosional.

\section{SIMPULAN}

Implementasi komunikasi dan analisa media penting dilakukan dalam evakuasi mahasiswa WNI dari Thailand selama pandemi COVID19. Komunikasi yang telah dibangun sebelumnya memiliki peran signifikan dalam membantu kelancaran proses evakuasi. Ketersediaan data dan informasi dengan akurasi dan kredibilitas tinggi penting dimiliki untuk membantu proses evakuasi yang dilakukan dari jarak jauh / remote. Banyaknya berita, rilis resmi, utasan media sosial yang diikuti dan ditemukan di ranah daring dimana terdapat indikasi disinformasi misinformasi dan fakenews menjadi tantangan tersendiri dalam proses evakuasi. Data dan informasi tersebut umumnya masih berupa puzzle berserakan yang membutuhkan penjernihan untuk mengetahui pesan utama yang terkandung di dalamnya. Analisa media yang dalam penelitian ini meliputi proses penelusuran informasi, verifikasi pengecekan fakta / fact checking dan analisis framming digunakan untuk menjernihkan informasi sebelum digunakan dalam proses evakuasi. Penguasaan multi-metode analisa ini penting di era digital mengingat banyaknya varian informasi yang tersedia. Banyaknya data dan informasi yang harus dianalisis dalam waktu singkat, dinamika perubahan situasi di dalam dan luar negeri, dan tekanan berbagai pihak menempatkan staff internasional office yang betugas di bagian pusat data dan komunikasi berada dalam tingkat stress yang snagat tinggi. Penguasaan pada teknik manajemen stress dan empati pada anggota tim dirasa mampu digunakan untuk meminimalisir efek negative analisa data dan informasi.

Pandemi COVID19 memberikan pelajaran berharga pada proses internasionalisasi yang sedang gencar dilakukan oleh kalangan perguruan tinggi di Indonesia. Situasi pandemi seperti COVID19 bukan tidak mungkin akan kembali terjadi pada tahun tahun mendatang. Kesiapan atas benefit dan resiko harus dapat diantisipasi perguruan tinggi. Evakuasi WNI bukan hanya tugas pemerintah sebagai bentuk hadirnya negara dalam perlindungan warganya di luar negeri. Setiap penyelenggara hubungan luar negeri juga memiliki kewajiban yang sama. Maka proses evakuasi mandiri ini boleh dilakukan secara oleh perguruan tinggi sebagai pengirim WNI ke luar negeri.

Berdasarkan temuan dalam penelitian prospek pengembangan hasil penelitian masih terbuka lebar. Proses internasionalisasi perguruan tinggi di Indonesia saat ini gencar dilakukan. Namun proses ini masih minim referensi dan membutuhkan banyak best practice sebagai panduan saat menemukan situasi serupa. Langkah komunikasi international office IAIN Tulungagung dengan humas UNESA merupakan bukti pentingnya berbagi referensi dan best practice. Ada beberapa pengembangan kajian yang dapat dilakukan dari hasil penelitian ini. Pertama, Implementasi Komunikasi dan diplomasi publik di era digital menarik untuk diteliti. 
Dua, kajian keselamatan psikologis dalam kajian safety journalist juga menarik untuk diteliti lebih lanjut.

\section{DAFTAR PUSTAKA / REFERENCES}

AJI. 2019. 'Materi Pelatihan Hoax Busting and Digital Hygiene'. Semarang: AJI

Chambers, P., Jitpiromsri, S., \& Waitoolkiat, N. (2019). Introduction: Conflict in the Deep South of Thailand: Never-ending Stalemate?. Asian International Studies Review, 20(1), 1-23.

Chambers, P., \& Waitoolkiat, N. (2019). The Role of Security Forces in Thailand's Deep South Counter-Insurgency. Asian International Studies Review, 20(1), 53-77.

Direktorat Jenderal Pendidikan Islam. (2018). "Keputusan Direktur Jenderal Pendidikan Islam Nomor 129 Tahun 2018 tentang Petunjuk Teknis Pelaksanaan Kerja Sama Pada Perguruan Tinggi Keagamaan Islam Kementerian Agama”.Jakarta: Direktorat Jenderal Pendidikan Islam

Entman, R. M. (2007). Framing bias: Media in the distribution of power. Journal of communication, 57(1), 163-173.

Graves, L., \& Cherubini, F. (2016). The rise of fact-checking sites in Europe.

Hertog, J. K., \& McLeod, D. M. (2001). A multiperspectival approach to framing analysis: A field guide. In Framing public life (pp. 157-178). Routledge.

International Office IAIN Tulungagung. (2020). "Analisis Kegiatan Luar Negeri dan COVID19’. Tulungagung: International Office IAIN Tulungagung

International Office IAIN Tulungagung. (2020). “Analisis penutupan immigration checkpoint Bukit Kayu Hitam - Sadao, COVID19 Malaysia \& Thailand, Serta Rekomendasi Evakuasi”. Tulungagung: International Office IAIN Tulungagung

Jitpiromsri, S. (2019). The Deep South of Thailand: 15 Years in Fields of Open Conflict, Violence and Peace Narratives. Asian International Studies Review, 20(1), 79-108.

International Office IAIN Tulungagung. (2020). "Update penutupan immigration checkpoint Bukit Kayu Hitam - Sadao, COVID19 Malaysia \& Thailand, Serta Rekomendasi Evakuasi”. Tulungagung: International Office IAIN Tulungagung

Kementerian Pendidikan Nasional. (2007). “Peraturan Menteri Pendidikan Nasional Nomor 26 Tahun 2007 tentang Kerja Sama Perguruan Tinggi di Indonesia Dengan Lembaga Perguruan Tinggi atau Lembaga Lain di Luar Negeri”. Jakarta: Kementerian Pendidikan Nasional

Linstrom, M., \& Marais, W. (2012). Qualitative news frame analysis: A methodology. Communitas, 17, 21-38.

Liu, Z., Moshi, G. J., \& Awuor, C. M. (2019). Sustainability and Indicators of Newly Formed World-Class Universities (NFWCUs) between 2010 and 2018: Empirical analysis from the rankings of ARWU, QSWUR and THEWUR. Sustainability, 11(10), 2745.

Luhmann, N. (2000). The reality of the mass media (p. 1). Stanford, CA: Stanford University Press. 
Ireton, C., \& Posetti, J. (2018). Journalism, fake news \& disinformation: handbook for journalism education and training. UNESCO Publishing.

Mawby, B., \& Martin, S. (2016). Evacuation and repatriation of migrants in countries experiencing conflict or natural disaster.

McLuhan, M. (1962). “The Guttenberg Galaxy: The Making Of the typographic Man”. Toronto: Toronto University Press

Melissen, J. (2020). Consular diplomacy's first challenge: Communicating assistance to nationals abroad. Asia \& the Pacific Policy Studies.

Mosco, V. (2009). “The Political Economy of Communication Second Edition”. London; Sage Publication

Mulyana, D. (2003). “Metode Penelitian Komunikasi”.Bandung: PT Remaja Rosda Karya

Pamungkas, C. (2015). Global village dan Globalisasi dalam Konteks ke-Indonesiaan. Global Strategis, 9(2), 245-261.

Pan, Z., \& Kosicki, G. M. (1993). Framing analysis: An approach to news discourse. Political communication, 10(1), 55-75.

Rajbhandari, B., Phuyal, N., Shrestha, B., \& Thapa, M. (2020). Air Medical Evacuation of Nepalese Citizen During Epidemic of COVID-19 from Wuhan to Nepal. Journal of the Nepal Medical Association, 58(222).

Pemerintah Indonesia. (1999). "Undang Undang No 37 Tahun 1999 Tentang Hubungan Luar Negeri”. Lembaran Negara Republik Indonesia Tahun 1999 Nomor 156. Jakarta: Sekretariat Negara

Rakhmat, J. (2002.) “Metode Penelitian Komunikasi”. Bandung: PT Remaja Rosda Karya

Kementerian Luar Negeri Republik Indonesia. (2018). "Peraturan Menteri Luar Negeri Nomor 5 Tahun 2018 Tentang Perlindungan Warga Negara Indonesia di Luar Negeri". Jakarta: Direktorat Jenderal Peraturan Perundang Undangan Kementerian Hukum dan Hak Asasi Manusia Republik Indonesia

Kementerian Luar Negeri Republik Indonesia. (2008). "Peraturan Menteri Luar Negeri Nomor 4 Tahun 2008 Tentang Pelayanan Warga Pada Perwakilan Republik Indonesia Di Luar Negeri”. Jakarta: Kementerian Luar Negeri Republik Indonesia

Kementerian Sekretariat Negara. (2020). "Kebijakan Pelaksanaan Perjalanan Dinas Luar Negeri (PDLN) Dalam Upaya Pencegahan Coronavirus Disease (COVID19)”. Jakarta: Kementerian Sekretariat Negara

QS World University Rankings. (2020). "QS World University Rangkings Methodology Brief”. London: QS World University Rangkings

Times Higher Education. (2018)."Methodology for Overall and Subject Rankings for the Times Higher Education World University Rangkings 2019”. London: Times Higher Education

UNHCR \& Georgetown University. (2014)."Planned Relocation, Disaster and Climate Change: Consolidating Good Practiceand Preparing for the Future”. Washington: Georgetown University

Van Dijk, J. (2020). The network society. Sage. 
Wheeler, M., \& Chambers, P. (2019). The Tragedy of Conflict Irresolution: Peace Dialogue in Southernmost Thailand under Military Rule. Asian International Studies Review, 20(1), 25-52.

WHO. (2020). “Novel Coronavirus (2019-nCoV) Situation Report-10”. Jenewa: WHO

WHO. (2020). “Novel Coronavirus (2019-nCoV) Situation Report-11”. Jenewa: WHO

WHO. (2020). “Novel Coronavirus (2019-nCoV) Situation Report-22”. Jenewa: WHO

WHO. (2020). “Coronavirus Disease 2019 (COVID19) Situation Report - 38”. Jenewa: WHO

WHO. (2020). “Coronavirus Disease 2019 (COVID19) Situation Report - 39”. Jenewa: WHO

WHO. (2020). “Coronavirus Disease 2019 (COVID19) Situation Report - 40”. Jenewa: WHO

WHO. (2020). “Coronavirus Disease 2019 (COVID19) Situation Report - 41”. Jenewa: WHO

WHO. (2020). “Coronavirus Disease 2019 (COVID19) Situation Report - 42”. Jenewa: WHO

WHO. (2020). “Coronavirus Disease 2019 (COVID19) Situation Report - 43”. Jenewa: WHO

WHO. (2020). “Coronavirus Disease 2019 (COVID19) Situation Report - 44”. Jenewa: WHO

WHO. (2020). “Coronavirus Disease 2019 (COVID19) Situation Report - 45”. Jenewa: WHO

WHO. (2020). “Coronavirus Disease 2019 (COVID19) Situation Report - 46”. Jenewa: WHO

WHO. (2020). “Coronavirus Disease 2019 (COVID19) Situation Report - 47”. Jenewa: WHO

WHO. (2020). “Coronavirus Disease 2019 (COVID19) Situation Report - 48”. Jenewa: WHO

WHO. (2020). “Coronavirus Disease 2019 (COVID19) Situation Report - 49”. Jenewa: WHO

Wiksana, W. A. (2017). Studi Deskriptif Kualitatif tentang Hambatan Komunikasi Fotografer dan Model dalam Proses Pemotretan. Mediator: Jurnal Komunikasi, 10(1), 121131. 